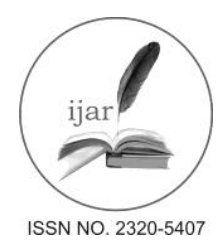

Journal homepage: http://www.journalijar.com
Journal DOI: 10.21474/IJAR01

RESEARCH ARTICLE

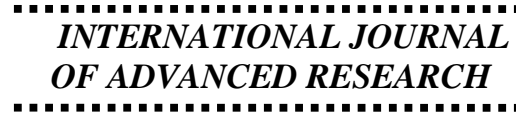

-

\title{
Screening of Aromatic rice (Joha) genotype against Sheath rot disease of Rice and its management under
} Field condition.

Manjay Singh ${ }^{1}$ and B.C. Das. ${ }^{2}$

1. Department of Plant Pathology, College of Agriculture, Assam Agricultural University, Jorhat-785013,India.

2. Regional Agricultural Research Station (RARS), Titabor-785630, Jorhat, Assam, India.

\section{Manuscript Info}

Manuscript History:
Received: 14 February 2016
Final Accepted: 26 March 2016
Published Online: April 2016

Key words:

Aromatic, Sheath rot, chemical control, Genotype Sarocladium oryzea, fungicides.

*Corresponding Author

Manjay Singh.

\begin{abstract}
An experiment was conducted at Regional Agriculture Research Station (RA RS) Titabar, under field conditions during kharif season 2015 against sheath rot of Aromatic rice. Sheath rot is one of the major disease of rice which subsequently reduce the rice production. In the present experiment 20 aromatic rice genotype were screened against Sheath rot of rice. Less disease incidence were recorded viz, Boga Jalsi, Boga Joha, Monika madhuri Joha, Tulsi Joha, Goul poriya Joha, Bokul Joha Monipuri Joha, Keteki Joha, and higher disease incidence were recorded viz, Kameni Joha, Badshabhog, Jalsa Joha, Krishna Joha, For management of the Sheath rot of aromatic rice few fungicides formulation were tested among them ICF-110 (Tricyclazole $45 \%+$ Hexaconazole $10 \%$ WG was found to be the superior as compared to other fungicides with reducing disease severity $83.86 \%$ and increased yield $185 \mathrm{~kg} / \mathrm{ha}$ followed by Companion and Carbendazim $50 \%$ WP.
\end{abstract}

Copy Right, IJAR, 2016.. All rights reserved.

\section{Introduction:-}

Rice is the staple food for most of the population in Asian countries such as India, China, Japan, Indonesia, etc. among the common rice cultivar of Assam, aromatic rice of this region enjoys top position in their popularity. Aromatic rice of Assam is the unique rice Under Sali (winter rice) traditionally known as 'Joha'. This class of rice has high demand in domestic market. It is very popular due to its inherent aroma, despite their low yield potential, this cultivar are grown for their high market social value and is much in demand for export. It is very popular for its flavor and is an indispensable feeding item during festival time. It has high fat, albumin and globulin content makes the Joha rice one of the suitable nutritious cereals, at present Assam has 20,000 ha area under Joha rice and produces about 30,000 metric tons of this aromatic rice every year. The area under Joha rice is however nominal owing to its poor yielding ability. Sheath rot of rice caused by Sarocladium oryzae (Sawada) Games and Hawksworth has gained the status of a major disease in rice (Reddy and Gosh, 1985) and yield loss varies from 9.6-85\% depending on weather condition during the crop growth period (Phookan and Hazarika, 1992). This disease was first reported in rice from Taiwan by Sawada (1922) and was subsequently reported from different rice growing ecosystem of world Agnihothrudu (1973) first time reported this disease from India and later it was reported from different part of the country. Keeping on this the present investigation was under taken to identify the resistant genotype/cultivar as a donor gene for the development of HYV and to evaluate the efficacy of new and commercially available fungicides for the control of Sheath rot disease of rice.

\section{Materials and methods:-}

For screening of rice genotype against sheath rot of rice an experiment was conducted at Regional Agriculture Research Station (RARS) Titabar, under field conditions during Kharif season 2015. Twenty aromatic rice germplasm were collected from germplasm collection centre RARS Titabar (Assam ) and screened against Sheath rot disease were viz, Boga Joha, Badshabhog, Jalsa Joha, Kanbagi Joha, Krishna Joha, Monika madhuri Joha, Goul poriya Joha, Bokul Joha, Govinda Bhog, Koli Joha, Tulasi Joha, Monipuri Joha, Keteki Joha, Kola Joha, Kameni Joha, Rampal Joha, Kaljira Joha, Ronga Joha, Kon Joha, These Twenty aromatic rice entries were shown 
in a field on 14.07.15 and each genotypes was maintained in 2 row with $20 \times 20 \mathrm{~cm}$ spacing. Number of replication was 2. The recommended dose of fertilizer NPK was applied, @60:20:40 kg/ha and the soil moisture content at $15-30 \mathrm{~cm}$ was regularly maintained. The fungus from the axenic culture of isolate was inoculated to the healthy rice plants of different genotypes at booting stage by grain insertion method as described by (Estrada et al., 1979). The observations of the appearance of disease from the each entry point 10 plant tillers was randomly selected and Percent disease incidence (PDI) and Percent disease severity (PDS) of sheath rot were recorded by using the disease rating 0-9 scale (IRRI 1998). Percent disease severity of varietal reactions was observed on the basis of rating scale (IRRI 1996). Before harvesting.

For management of the Sheath rot of aromatic rice, an experiment was conducted during Kharif 2015, with few fungicides formulation viz, ICF -110 (Tricyclazole 45\% + Hexaconazole 10\% WG), MERGER (Tricyclazole 18\% + Mancozeb 62\% WP), Tricyclazole 75\% WP, Hexaconazole 5\% EC, Mancozeb 75\% WP, Companion (Mancozeb $63 \%$ WP + Carbendazim $12 \%$ WP), Carbendazim 50\% WP, Control (Water spray). The field was layout with eight treatment replicated for two times, and all the agronomical practices were followed. Fertilizer application was done @ 60:20: 40 kg N,P,K./ha The Thirty- day old seedling of susceptible variety Krishna joha was transplanted with spacing $20 \times 15 \mathrm{~cm}$ on 15.08 .15 , The sprays of fungicides were done at 15 days interval, for three times starting from disease initiation (Booting stage). First spray was done on 05.10.2015 and the second spray on 20.10.15 and third spray was done on 5.11.15. The observation on Percent Disease Severity (PDS) was done at maturity with 0-9 scale and yield was recorded from each treatment. The grain yield was recorded at 14 percent moister after 4-5 days of sun drying of the rice grains after harvest. The disease severity scale 0-9 SES (IRRI, 1988) are given below:

Disease severity Scale (IRRI, 1988)

\begin{tabular}{|c|c|c|}
\hline Scale & Severity & Reaction \\
\hline $\mathbf{0}$ & No incidence & Immune \\
\hline $\mathbf{1}$ & 1 Less than $1 \%$ & HR \\
\hline $\mathbf{3}$ & $1-5 \%$ & $\mathrm{R}$ \\
\hline $\mathbf{5}$ & $6-25 \%$ & $\mathrm{MR}$ \\
\hline $\mathbf{7}$ & $26-50 \%$ & $\mathrm{~S}$ \\
\hline $\mathbf{9}$ & $51-100 \%$ & HS \\
\hline
\end{tabular}

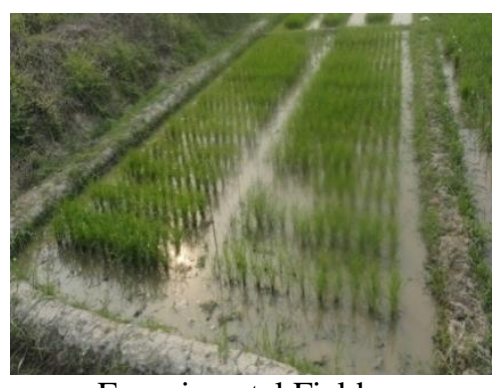

Experimental Field

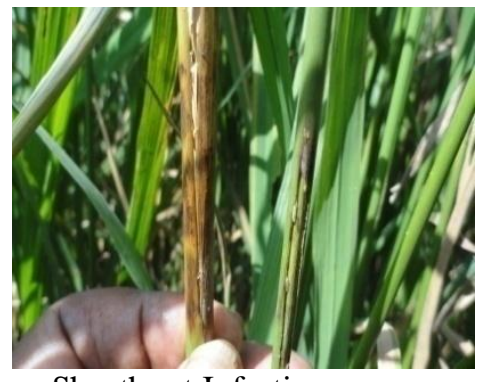

Sheath rot Infection

\section{Results and discussion:-}

Twenty aromatic rice varieties were evaluated against Sheath rot disease. The percent disease incidence (PDI) and Percent Disease severity (PDS) of all the entries were recorded. Eight entries viz., Boga Jalsi, Boga Joha, Monika madhuri Joha, Goul poriya Joha, Bokul Joha, Tulasi Joha, Monipuri Joha, Keteki Joha, were recorded as highly resistant (Score-1). Three entries viz. Govinda Bhog, Kon Joha, Koli Joha, were recorded as resistance (Score-3), Five entries viz, Kola Joha, Kaljira Joha, Rampal Joha, Ronga Joha, Kanbagi Joha, were recorded as Moderately resistance (Score-5). Four entries viz. Kameni Joha, Badshabhog, Jalsa Joha, Krishna Joha, were recorded as susceptible reactions (Score-7) and non of the single variety were recorded as highly susceptible reactions (Score-9) (Table-1). Kindo et al.,(2015) screened the aromatic rice at Indira Gandhi Krishi Vishvavidyalaya, Raipur and reported out of twenty two of local aromatic rice cultivars, eighteen were found to be resistant against the Sheath rot disease. They also reported Badsabhog was susceptible which was similar to present investigation.

Table1. Reactions of the aromatic rice varieties against sheath rot of rice

\begin{tabular}{|c|c|c|l|}
\hline Score & $\begin{array}{c}\text { Disease } \\
\text { reaction }\end{array}$ & Total & \multicolumn{1}{c|}{ Aromatic Variety } \\
\hline $\mathbf{0}$ & Immune & $\mathbf{0}$ & No \\
\hline $\mathbf{1}$ & HR & $\mathbf{8}$ & $\begin{array}{l}\text { Boga Jalsi, Boga Joha, Monika madhuri Joha, Goul poriya Joha, Bokul Joha, } \\
\text { Tulasi Joha, Monipuri Joha, Keteki Joha, }\end{array}$ \\
\hline $\mathbf{3}$ & $\mathbf{R}$ & $\mathbf{3}$ & Govinda Bhog, Kon Joha, Koli Joha, \\
\hline $\mathbf{5}$ & $\mathbf{M R}$ & $\mathbf{5}$ & Kola Joha, Kaljira Joha, Rampal Joha, Ronga Joha, Kanbagi Joha, \\
\hline $\mathbf{7}$ & $\mathbf{S}$ & $\mathbf{4}$ & Kameni Joha, Badshabhog, Jalsa Joha, Krishna Joha, \\
\hline $\mathbf{9}$ & HS & $\mathbf{0}$ & No \\
\hline
\end{tabular}


The evaluation of fungicides was done for the management of Sheath rot disease of Aromatic rice under field condition. It was observed that all the fungicides significantly suppressed the percent disease severity (PDS) of Sheath rot with increased yield as compared to control. The minimum percent disease severity (PDS) (4.49) was exhibited when it was treated with ICF -110 (Tricyclazole 45\% + Hexaconazole 10\% WG) as compared to other fungicides with increased yield followed by companion and Carbendazim 50\% WP. Although, Tricyclazole $75 \%$ WP, Hexaconazole 5\% EC and Mancozeb 75\%WP. Suppresses the ShR disease, but there was no significant difference in yield.(Table -2). Maximum percent disease severity (27.83) was recorded in the control, Sharma et al.,(2013)at G.B Pant University reported that, tebuconazole at $10 \mathrm{ppm}$ caused maximum inhabitation of S.oryzae, followed by carbendazim under field condition. Doden et al., (1996) reported the efficacy of carbendazim, propiconzol, mancozeb, edimmancozeb, edifenphos and Tricyclazole in controlling Sheath rot caused by $S$. oryzae. Chinnaswamy et al., (1981) found that carbendazim was the most effective against Sheath rot of rice, so from the finding it is clear that the emphasis should be continued in developing the resistant cultivar/germplasm and effective management practices to obtain the better yield production against Sheath rot.

Table 2. Per cent Disease incidence (DI) and Per cent Disease Severity (DS) of Sheath rot of Rice with application of different fungicides under field condition

\begin{tabular}{|c|c|c|c|c|c|c|}
\hline Fungicides & $\begin{array}{l}\text { Doses(g or ml / } \\
\text { lit of water) }\end{array}$ & $\% \mathrm{DI}$ & $\begin{array}{l}\text { \% DI } \\
\text { (Control) }\end{array}$ & $\% \mathrm{DS}$ & $\begin{array}{l}\text { \%DS } \\
\text { (Control) }\end{array}$ & $\begin{array}{l}\text { Yield } \\
\text { (kg/ha) }\end{array}$ \\
\hline $\mathbf{T}_{1}=\mathrm{ICF}-110$ & $1.0 \mathrm{~g}$ & $\begin{array}{c}11.02 \\
(19.37)\end{array}$ & 79.47 & $\begin{array}{c}4.49 \\
(12.25)\end{array}$ & 83.86 & $\begin{array}{c}185 \\
\mathrm{~kg} / \mathrm{ha}\end{array}$ \\
\hline $\begin{array}{l}\mathbf{T}_{2}=\text { MERGER } \\
\text { (Tricyclazole } 18 \%+ \\
\text { Mancozeb } 62 \% \mathrm{WP} \text { ) }\end{array}$ & 2.5 & $\begin{array}{c}17.84 \\
(24.95)\end{array}$ & 66.76 & $\begin{array}{c}8.08 \\
(16.43)\end{array}$ & 70.96 & $\begin{array}{c}165 \\
\mathrm{~kg} / \mathrm{ha}\end{array}$ \\
\hline $\mathbf{T}_{\mathbf{3}}=$ Tricyclazole $75 \% \mathrm{WP}$ & 0.6 & $\begin{array}{c}19.43 \\
(26.13)\end{array}$ & 63.80 & $\begin{array}{c}9.14 \\
(17.56)\end{array}$ & 67.15 & $\begin{array}{c}160 \\
\mathrm{~kg} / \mathrm{ha}\end{array}$ \\
\hline $\mathbf{T}_{4}=$ Hexaconazole $5 \% \mathrm{EC}$ & $2.0 \mathrm{ml}$ & $\begin{array}{c}20.41 \\
(26.85) \\
\end{array}$ & 61.97 & $\begin{array}{c}10.03 \\
(18.43) \\
\end{array}$ & 63.95 & $\begin{array}{c}161 \\
\mathrm{~kg} / \mathrm{ha}\end{array}$ \\
\hline $\mathbf{T}_{\mathbf{5}}=$ Mancozeb $75 \% \mathrm{WP}$ & $2.0 \mathrm{~g}$ & $\begin{array}{c}21.15 \\
(27.35) \\
\end{array}$ & 60.59 & $\begin{array}{c}11.22 \\
(19.55) \\
\end{array}$ & 59.68 & $\begin{array}{c}162 \\
\mathrm{~kg} / \mathrm{ha}\end{array}$ \\
\hline $\begin{array}{c}\mathbf{T}_{\mathbf{6}}=\text { Mancozeb } 63 \% \mathrm{WP}+ \\
\begin{array}{l}\text { Carbendazim } 12 \% \mathrm{WP} \\
\text { (Companion) }\end{array}\end{array}$ & $1.5 \mathrm{~g}$ & $\begin{array}{c}12.72 \\
(20.85)\end{array}$ & 76.30 & $\begin{array}{c}5.78 \\
(13.81)\end{array}$ & 79.23 & $\begin{array}{c}177 \\
\mathrm{~kg} / \mathrm{ha}\end{array}$ \\
\hline $\mathbf{T}_{7}=$ Carbendazim $50 \% \mathrm{WP}$ & 1.0 & $\begin{array}{c}14.83 \\
(22.63)\end{array}$ & 72.37 & $\begin{array}{c}6.53 \\
(14.77)\end{array}$ & 76.53 & $\begin{array}{c}172 \\
\mathrm{~kg} / \mathrm{ha}\end{array}$ \\
\hline $\mathbf{T}_{\mathbf{8}}=$ Control (Water spray) & & $\begin{array}{r}53.68 \\
(47.06) \\
\end{array}$ & & $\begin{array}{r}27.83 \\
(31.82) \\
\end{array}$ & & $\begin{array}{c}155 \\
\mathrm{~kg} / \mathrm{ha}\end{array}$ \\
\hline S.Ed \pm & & 0.77 & & 0.83 & & 9.16 \\
\hline $\mathrm{CD}(\mathrm{P}=0.05)$ & & 1.55 & & 1.66 & & 290.00 \\
\hline
\end{tabular}

\section{Literature cited:-}

1. Agnihothrudu, V. (1973) Acrocylindrium oryzae Sawada sheath rot on paddy. Kavaka. 1 : 69-71.

2. Chinnaswamy, R., Nair, M. C. and Menon, M. R. (1981). Comparative efficacy of certain fungicides in the control of sheath rots of rice. Agricultural Research Journal of Kerala. 19 (2): 86-88.

3. Dodan, D. S., Singh, R., Sunder, S. and Singh, R. (1996) Efficacy of fungi against sheath rots of rice. Indian journal of Mycology and Plant pathology, 26(3):283-284

4. Estrada, B.A., Sanchez, L.M. and Crill., P. (1979) Evaluation of Sheath rot screening method and the effect of the disease on grain yield of rice. Plant Dis. Reptr.63: 908-911.

5. IRRI (1996). International Rice Research Institute (IRRI). Annual report of rice. Page - 25.

6. Kindo Deepmala, Bhagat Kumar Rakesh and Tiwari P.K.(2015) Screening of Aromatic Rice Entries against Sheath Rot of Rice Under Field Condition .Trends in Biosciences 8(2) ISSN 0974-8, 462-46

7. Lalan Sharma1, D. T. Nagrale1*, S. K. Singh, K. K. Sharma and A. P. Sinha (2013) A study on fungicides potential and incidence of sheath rot of rice caused by Sarocladium oryzae (Sawada) Journal of Applied and Natural Science 5 (1): 24-29 
8. Phookan, A.K. and Hazarika, D.K. (1992) Distribution of sheath rot (ShR) in six agroclimatic zones of Assa m, India. IRRN. 17: 16.

9. Reddy, C.S. and Ghosh, A. (1985) Sheath rot incidence and yield losses in rice due to the joint infection of rice tungro virus and sheath rot fungus. Indian Phytopath. 38 (1): 165.

10. Sawada, K. (1922) Descriptive catalogue of Formosan fungill Rep. Govt. Res. Inst. Deptt. Agric. Formosa. 2: 135. 